\title{
SURGICAL SAFETY AND ADVERSE EVENTS IN THE OPERATING ROOMS OF OBSTETRIC DEPARTMENT AT AL-AZHAR UNIVERSITY HOSPITAL
}

\author{
By \\ Ahmed Abd El-Ghafour El-Basuony Abou Zid, Ismail Talaat El-Garhy \\ and Adel Aly El-Boghdady \\ Department of Obstetrics and Gynecology, Faculty of Medicine, Al-Azhar University \\ Corresponding author: Ahmed Abd El-Ghafour El-Basuony Abou Zid, \\ E-mail: dr_ahmed_basiony@hotmail.com
}

\begin{abstract}
Background: Most surgical safety interventions have focused on the operating room. Since more than half of all surgical errors occur outside the operating room. It is likely that a more substantial improvement in outcomes can be achieved by targeting the entire surgical pathway. Evidence-based elements in patients who undergo Cesarean delivery (CD) may decrease the incidence of this major complication.
\end{abstract}

Objective: To improve the health and well-being of pregnant women undergoing obstetric surgery in $\mathrm{Al}$ Azhar University Hospital through making a relation between cesarean section in full term pregnant women and surgical site infection postoperatively.

Patients and methods: This was a cross sectional study, completed at working rooms of obstetric office at Al-Hussein Hospital, Al-Azhar University, from October 2019 till July 2020. Test size was determined utilizing Open EPI program. Test size was 150.

Results: There were 29 (19.33\%) with diabetes, 38 (25.33\%) with hypertension, 10 (6.67\%) with cardiac diseases, $6(4 \%)$ with HCV positive, 30 (20\%) with anemia, 5 (3.33\%) with thrombocytopenia and $75(50 \%)$ with previous CS, $15(10 \%)$ with previous $\mathrm{D} \& \mathrm{C}$ and $2(1.33 \%)$ with other past activities. There were 133 $(88.6 \%)$ cases utilizing spinal sedation, $12(8 \%)$ utilizing general sedation, and $5(3.33 \%)$ utilizing general sedation. The biggest level of patient went through activities in which things of careful wellbeing agenda sign in were satisfied aside from that patients had affirmed site and checked it. The biggest level of patient went through activities in which things of careful security agenda Time out were not satisfied aside from that Surgeon, sedation expert and medical caretaker verbally affirm system. Anti-toxin prophylaxis been given inside the last 60 mins before cut. Anesthesia group audits and Nursing group affirmed sanitization.

Conclusion: There was a strong connection between applying careful security agenda and result of medical procedure.

Keywords: Surgical Safety, Adverse Events, Operating rooms, Obstetric Department.

\section{INTRODUCTION}

Medical contaminations

infections services related healthcare-associated worldwide as a genuine general medical issue, as the most continuous antagonistic functions identified with persistent consideration, and they are related with high bleakness and mortality, and expanded length of remain and clinic costs (Balsells et al., 2019). 
Among the HAIs, careful site contamination surgical site infection (SSI) has a noticeable job, which can be shown as long as 30 days after medical procedure, or as long as 90 days after if an embed is utilized, and are classified as indicated by the level of inclusion, specifically: superficial entry point, profound cut, or organ and additionally space disease (Prates et al., 2018). Careful site contamination is one of the fundamental focuses of epidemiological reconnaissance in wellbeing organizations. In immature and nonindustrial nations, it is assessed that SSI can affect up to one third of patients going through surgeries (Malizos and KirketerpMoller, 2016).

Wellbeing society is characterized as the aggregate result of individual and gathering esteems, perspectives and examples of practices in security execution. The qualities of a solid and proactive security culture incorporate the dedication of the initiative to talk about and gain from mistakes, to archive and improve tolerant wellbeing, to empower and rehearse collaboration, to spot likely perils, to utilize frameworks for announcing and examining unfavorable functions and to commend laborers as legends improving wellbeing instead of as scalawags submitting blunders. Associations with a positive wellbeing society are described by interchanges established on common trust, by shared impression of the significance of security and by trust in the viability of preventive measures (Nyarugwe et al., 2016).

Components related with a low pace of unfriendly functions were lacking revealing and insufficient documentation inside the clinic clinical records. The examination featured the need to improve the patient wellbeing society among medical care suppliers at Ain Shams University clinics and to build up their eagerness to act to decrease quiet mischief (El-Sherbiny et al., 2020).

An ongoing precise survey proposed that very nearly 1 out of 10 patients admitted to emergency clinic experience an unfavorable function, with tasks representing $40 \%$ of these events. Explicit consideration is being paid to group connections and correspondence. Much as a plane pilot must depend on the ground team, flight work force, and air traffic regulators for a protected and fruitful flight, a specialist must depend on the anesthetist and attendants during an activity. The normal component basic for progress among these groups is acceptable correspondence. Correspondence disappointments happen in around $30 \%$ of group trades in the working room, and $33 \%$ of these disappointments have quick impacts, for example, failure or group strain (Singh et al., 2018). Disappointments in correspondence can have critical effect on quiet wellbeing in the working room, and their decrease is a basic piece of an agenda to improve careful security (Siu et al., 2016).

The aim of the present work was to examine the connection among cesarian section and frequency of careful site contamination in the wake of applying careful wellbeing agenda in Obstetrics at Al-Hussein Hospital, Al-Azhar University. 


\section{SUBJECTS AND METHODS}

This was a cross sectional examination, completed at Obstetrics and Gynecology Department, Al-Hussein Hospital, AlAzhar University, from October 2019 till July 2020.

\section{Inclusion criteria:}

- Any women attended for delivery by C.S.

- Full term $>37 \mathrm{w}$.

- All women were hospitalized postoperatively for more than $24 \mathrm{~h}$.

- Women should be aged from 20-35 years with BMI average from 30-40.

\section{Exclusion criteria:}

- Undetermined gestational age.

- Emergency procedure for unstable patient.

Test Size: As the rate of careful site disease was 3.4\% (Carvalho et al., 2017), and number of cases taking care AlHussein Hospital Al-Azhar University 40 every week so in one year 1920 so test size is 110 .

Test size was determined utilizing Open EPI program with certainty limit 3.3 and configuration impact 1.

We added 40 cases because of a paranoid fear of non-reaction or nonconformist, so test size was 150 .
All patients were exposed to obstetric and clinical history, total examination, assessment of fetal prosperity, lab appraisal, total blood check, CRP and gathering, liver chemicals, kidney capacities, irregular glucose.

\section{Interventions:}

- WHO and CDC rules for careful security was directed to each patient.

- The Department of Health's High Impact Intervention Care Bundle to forestall careful site disease suggested that anti-toxin prophylaxis was allowed inside an hour prior to cut.

- We managed anti-toxins to practically all ladies included.

- Surgical wellbeing agenda as indicated by WHO and CDC (Safety and Organization, 2009) was utilized.

\section{Statistical analysis:}

Analysis of data was done using Statistical Package for the Social Sciences version 20 (SPSS Inc., Chicago, IL, USA). Quantitative variables were described in the form of mean, standard deviation and median (IQR). Qualitative variables were described as number and percent. In range. Qualitative variables were compared using chi-square (X2) test or Fisher's exact test when frequencies were below five. A $\mathrm{P}$ value $<0.05$ is considered significant.

\section{RESULTS}

Among the studied cases, the mean age was $27.51( \pm 13.72 \mathrm{SD})$ with range (20$35)$, the mean BMI was $35.4( \pm 2.74 \mathrm{SD})$ with range $(30.2-39.7)$, the mean Gravidity was $2.36( \pm 1.4 \mathrm{SD})$ with range
(1-6), the mean Parity was $1.05( \pm 1.41$ $\mathrm{SD})$ with range (0-5) and the mean Gestational age was $38.49( \pm 1.08$ SD) with range (37-40) (Table 1). 
Table (1): Distribution of the studied cases according to demographic data $(n=150)$

\begin{tabular}{|c|c|c|}
\hline Demographic data & No. & $\%$ \\
\hline \multicolumn{3}{|l|}{ Age (years) } \\
\hline Min. - Max. & \multicolumn{2}{|c|}{$20.0-35.0$} \\
\hline Mean \pm SD. & \multicolumn{2}{|c|}{$27.51 \pm 4.60$} \\
\hline Median (IQR) & \multicolumn{2}{|c|}{$27.5(24.0-32.0)$} \\
\hline \multicolumn{3}{|l|}{ BMI } \\
\hline Min. - Max. & \multicolumn{2}{|c|}{$30.2-39.7$} \\
\hline Mean \pm SD. & \multicolumn{2}{|c|}{$35.40 \pm 2.74$} \\
\hline Median (IQR) & \multicolumn{2}{|c|}{$35.7(33.1-37.7)$} \\
\hline \multicolumn{3}{|l|}{ Gravidity } \\
\hline Min. - Max. & \multicolumn{2}{|c|}{$1.0-6.0$} \\
\hline Mean \pm SD. & \multicolumn{2}{|c|}{$2.36 \pm 1.49$} \\
\hline Median (IQR) & \multicolumn{2}{|c|}{$2.0(1.0-3.0)$} \\
\hline \multicolumn{3}{|l|}{ Parity } \\
\hline Min. - Max. & \multicolumn{2}{|c|}{$0.0-5.0$} \\
\hline Mean \pm SD. & \multicolumn{2}{|c|}{$1.05 \pm 1.41$} \\
\hline Median (IQR) & \multicolumn{2}{|c|}{$0.5(0.0-1.0)$} \\
\hline \multicolumn{3}{|l|}{ Gestational age (weeks) } \\
\hline Min. - Max. & \multicolumn{2}{|c|}{$37.0-40.0$} \\
\hline Mean \pm SD. & \multicolumn{2}{|c|}{$38.49 \pm 1.08$} \\
\hline Median (IQR) & \multicolumn{2}{|c|}{$39.0(38.0-39.0)$} \\
\hline
\end{tabular}

As regard preoperative risk factors there were $29(19.33 \%)$ with diabetes, 38 $(25.33 \%)$ with hypertension, $10(6.67 \%)$ with cardiac diseases, 6 (4\%) with HCV positive, $30(20 \%)$ with anemia, $5(3.33 \%)$ with thrombocytopenia, and 75 (50\%) with previous CS, 15 (10\%) with previous $\mathrm{D} \& \mathrm{C}$ and $2(1.33 \%)$ with other previous operations (Table 2).

Table (2): Distribution of the studied cases according to preoperative risk factors $(\mathbf{n}=150)$

\begin{tabular}{|l|c|c|}
\hline Preoperative risk factors & No. & \% \\
\hline Diabetes & 29 & 19.33 \\
\hline Hypertension & 38 & 25.33 \\
\hline Cardiac disease & 10 & 6.67 \\
\hline HCV positive & 6 & 4.0 \\
\hline Anemia & 30 & 20.0 \\
\hline Thrombocytopenia & 5 & 3.33 \\
\hline Previous CS & 75 & 50.0 \\
\hline P1 & 39 & 26.0 \\
\hline P2 & 10 & 6.67 \\
\hline P3 and more & 26 & 17.33 \\
\hline Previous D\&C & 15 & 10.0 \\
\hline Other previous operations & 2 & 1.33 \\
\hline
\end{tabular}

In the present study, $5.3 \%$ of studied cases entered ICU post operation and adverse events represented in $25.33 \%$ intra-operative hemorrhage and 1.3\% bladder injury. There was no infectious adverse event (Table 3). 
Table (3): Intra-operative complications in studied cases

\begin{tabular}{|c|c|c|}
\hline Adverse events & No. & $\%$ \\
\hline Intra-operative hemorrhage & 38 & 25.33 \\
\hline $\begin{array}{l}\text { Organ injury during a procedure } \\
\text { (bladder injury) }\end{array}$ & 2 & 1.3 \\
\hline Post-operative ICU admission & 8 & 5.3 \\
\hline Unplanned return to OR & 1 & 0.67 \\
\hline Intra-operative death & 0 & 0.0 \\
\hline - $\quad$ SSI during hospitalization & 0 & 0.0 \\
\hline
\end{tabular}

There was a highly statistically significant difference between the studied groups as regard anesthesia safety check completed, required monitoring as pulse oximeter on patient and functioning, patient asked if has a known allergy, blood availability for risk of $>500 \mathrm{ml}$ blood loss and statistically significant difference between the studied groups as regard patient confirm procedure and consent and essential radiological imaging displayed (Table 4).

Table (4): Item of checklist about "sign in" comparison between studied groups according to complication $(n=150)$

\begin{tabular}{|l|c|c|c|c|c|c|}
\hline Groups & \multicolumn{2}{|c|}{$\begin{array}{c}\text { Uncomplicated } \\
\text { Items }\end{array}$} & \multicolumn{2}{c|}{$\begin{array}{c}\text { Complicated } \\
\text { (n=52) }\end{array}$} & $\chi^{2}$ & P \\
\hline Patient has confirmed: & No. & $\%$ & No. & $\%$ & & \\
\hline Identity & & & & & & \\
\hline Site & 93 & 94.90 & 52 & 100.0 & 2.745 & 0.097 \\
\hline Procedure & 40 & 40.81 & 17 & 32.69 & 0.951 & 0.329 \\
\hline Consent check & 94 & 95.92 & 45 & 86.54 & 4.399 & 0.036 \\
\hline $\begin{array}{l}\text { Anesthesia safety } \\
\text { completed }\end{array}$ & 98 & 100.0 & 47 & 90.38 & 9.748 & 0.002 \\
\hline $\begin{array}{l}\text { Required monitoring as pulse } \\
\text { oximeter on patient and } \\
\text { functioning }\end{array}$ & 96 & 97.96 & 41 & 78.85 & 15.68 & $<0.001$ \\
\hline $\begin{array}{l}\text { Patient asked if has a known } \\
\text { allergy }\end{array}$ & 98 & 100.0 & 44 & 84.61 & 15.93 & $<0.001$ \\
\hline $\begin{array}{l}\text { Difficult airway/aspiration } \\
\text { risk? }\end{array}$ & 86 & 87.76 & 46 & 88.46 & 0.016 & 0.899 \\
\hline $\begin{array}{l}\text { Essential radiological imaging } \\
\text { displayed? }\end{array}$ & 95 & 96.94 & 43 & 82.69 & 9.369 & 0.002 \\
\hline $\begin{array}{l}\text { Blood availability for risk of } \\
>\text { 500 ml blood loss? }\end{array}$ & 96 & 97.96 & 37 & 71.15 & 24.29 & $<0.001$ \\
\hline $\begin{array}{l}\text { Venous thromboembolism } \\
\text { prophylaxis }\end{array}$ & 6 & 6.12 & 1 & 1.93 & 1.347 & 0.247 \\
\hline
\end{tabular}

There was a statistically significant difference between the studied groups as regard surgeon, anesthesia professional and nurse verbally confirm site, procedure and the critical or unexpected steps (Table 5). 
AHMED A. E. ABOU ZID et al.,

Table (5): Item of checklist about "Time out" comparison between studied groups according to complication $(n=150)$

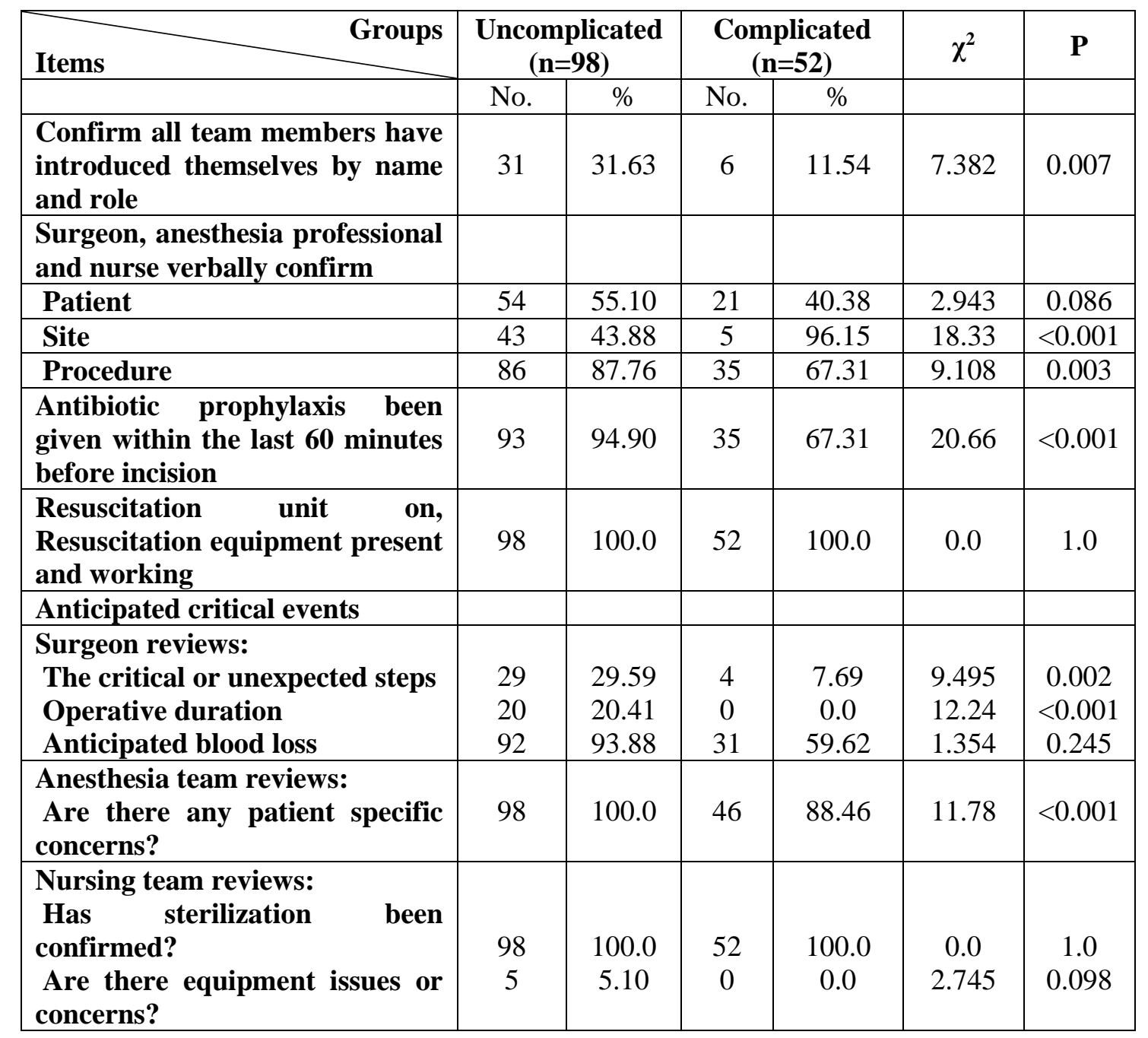

There was a highly statistically significant difference between the studied groups as objective airway evaluation performed, pulse oximeter used and sponge count completed and statistically significant difference between the studied groups as regard prophylactics antibiotic given appropriately, oral confirmation of patient's identity and operative site, and all six safety indicators performed (Table 6). 
Table (6): Selected process measures comparison between studied groups according to complication $(n=150)$

\begin{tabular}{|c|c|c|c|c|c|c|}
\hline $\begin{array}{ll}\text { Process measures } & \text { Groups } \\
\end{array}$ & $\begin{array}{r}\text { Uncor } \\
(\mathbf{r}\end{array}$ & $\begin{array}{l}\text { licated } \\
\text { 8) }\end{array}$ & & $\begin{array}{l}\text { icated } \\
52)\end{array}$ & $\chi^{2}$ & $\mathbf{P}$ \\
\hline & No. & $\%$ & No. & $\%$ & & \\
\hline $\begin{array}{l}\text { 1- Objective airway evaluation } \\
\text { performed }\end{array}$ & 81 & 82.65 & 24 & 46.15 & 21.55 & $<0.001$ \\
\hline 2- Pulse oximeter used & 96 & 97.96 & 41 & 78.85 & 15.68 & $<0.001$ \\
\hline 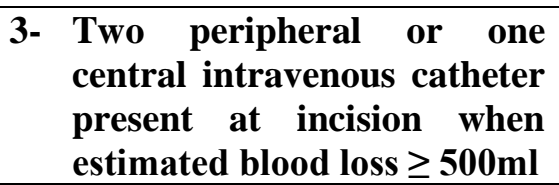 & 98 & 100.0 & 52 & 100.0 & 0.0 & 1.0 \\
\hline $\begin{array}{l}\text { 4- Prophylactics antibiotic } \\
\text { given appropriately }\end{array}$ & 67 & 68.37 & 27 & 51.92 & 3.927 & 0.048 \\
\hline $\begin{array}{l}\text { 5- } \begin{array}{l}\text { Oral confirmation } \\
\text { patient's identity }\end{array} \\
\text { operative site }\end{array}$ & 16 & 16.33 & 2 & 3.85 & 5.011 & 0.025 \\
\hline 6- Sponge count completed & 81 & 82.65 & 20 & 38.46 & 30.16 & $<0.001$ \\
\hline 7- All six safety indicators & 76 & 77.55 & 28 & 53.85 & 8.979 & 0.003 \\
\hline
\end{tabular}

There was no statistically significant difference between the two groups as regard fetal outcome (Table 7).

Table (7): Comparison between studied groups according to Fetal outcome $(n=25)$

\begin{tabular}{|c|c|c|c|c|c|c|}
\hline Groups & \multicolumn{2}{|c|}{$\begin{array}{c}\text { Uncomplicated } \\
(\mathbf{n = 9 8})\end{array}$} & \multicolumn{2}{c|}{$\begin{array}{c}\text { Complicated } \\
(\mathbf{n = 5 2})\end{array}$} & $\boldsymbol{\chi}^{\mathbf{2}}$ & P \\
\hline & No. & $\%$ & No. & $\%$ & & \\
\hline Good APGAR score & 81 & 82.65 & 36 & 69.23 & 3.567 & 0.059 \\
\hline Entered incubation & 11 & 11.22 & 4 & 7.69 & 0.471 & 0.493 \\
\hline Congenital malformation & 1 & 1.02 & 1 & 1.92 & 0.210 & 0.646 \\
\hline Dead fetus & 0 & 0.0 & 1 & 1.92 & 1.897 & 0.1685 \\
\hline
\end{tabular}

\section{DISCUSSION}

In this investigation, we revealed that preoperative danger factors showed $19.33 \%$ with diabetes, $25.33 \%$ with hypertension, $6.67 \%$ with cardiac infection, $4 \%$ with $\mathrm{HCV}$ positive, $20 \%$ with anemia, $3.33 \%$ with thrombocytopenia, $50 \%$ with previous CS, $10 \%$ with previous $\mathrm{D} \& \mathrm{C}$, and $1.33 \%$ with different past activities. We confirmed that that $5.33 \%$ of considered cases entered ICU post activity and antagonistic functions in our examination spoke to in
$25.33 \%$ intra-employable drain and $1.3 \%$ bladder injury, there was no irresistible unfavorable function in our investigation.

In the current examination, there was an exceptionally measurably huge contrast between the confounded and nonconvoluted gatherings as respect to anesthesia security check finished, Required observing as heartbeat oximeter on patient and working, patient inquired as to whether has a known hypersensitivity, blood accessibility for danger of $>500 \mathrm{ml}$ blood misfortune, and 
factually critical distinction between the contemplated bunches as respect patient affirm procedure and consent and essential radiological imaging showed.

To execute the agenda, all locales needed to present a proper delay in care during medical procedure for preoperative group presentations and briefings and postoperative debriefings, group rehearses that have been demonstrated to be related with improved security cycles and mentalities and with a pace of entanglements and passing decreased by as much as $80 \%$ (Mazzocco et al., 2011).

In the current investigation, we detailed that there was a profoundly measurably huge distinction between the convoluted and non-muddled gatherings as respect to Surgeon, sedation expert and attendant verbally affirm site. Antibiotic prophylaxis been given inside the most recent an hour prior to cut.

A methodical survey by De Jager et al. (2016) showed decrease of confusions, basically in non-industrial nations.

In spite of this proof, a Canadian report by Urbach et al. (2014) showed a critical decrease in the danger of entanglements, readmissions, and mortality identified with the employable method.

Moreover, the investigation by Boaz et al. (2014) that planned to break down the impacts of the usage of the agenda in muscular medical procedures, did not exhibit a critical decrease in the pace of careful disease and other postoperative difficulties.

In the current investigation, we exhibited that there was a profoundly factually critical distinction between the convoluted and non-muddled gatherings as respect the example is marked and measurably huge contrast between the examined bunches as respect the name of method recorded and surgeon, sedation expert and medical caretaker review the vital worries for recuperation and the executives of this patient.

This was in concordance with Singh et al. (2018) who suggested that the careful security agenda ought to be received by all careful consideration suppliers and their individual organizations to improve understanding wellbeing.

Against our outcomes came the after effects of Russ et al. (2015) who showed that staffs have revealed in interviews that utilization of the agenda can intrude on the presentation of other security undertakings that are at the same time being performed by people. Furthermore, without a firm feeling of promise to the agenda it might turn into a standard movement of confirming boxes without really driving conduct change or improvement.

Agenda execution energized the organization of anti-infection agents in the working room as opposed to in the preoperative wards, where deferrals are successive. The agenda gave extra oral affirmation of suitable anti-toxin use, expanding the observance frequency on or after 56 to $83 \%$; this negotiation alone has be present give the impression to lessen the pace of careful site sullying by 33 to 88\% (Platt et al., 2010).

Opportune anti-infection organization has been connected to abatement in careful site disease. In one investigation, pre-entry point anti-microbials were not controlled $12.1 \%$ of the time. After presentation of an agenda, this number 
diminished to $7.1 \%(\mathrm{p}=0.015)($ De Vries et al., 2010).

Other conceivably lifesaving measures were likewise bound to be founded, including a target aviation route assessment and utilization of heartbeat oximetry, however the adjustment in these measures was less emotional (Shiralkar, 2017).

Presenting the agenda can at first be seen as troublesome, staff individuals regularly have a positive demeanor after it has been started (Lingard et al., 2010).

In this investigation, we represented that the biggest level of examined cases (78\%) got hatchling with great Apgar score with no measurably critical contrast between the confounded and non-muddled gatherings as respect fetal result.

This came in concurrence with who expressed that, while breaking down the frequency of SSI in clean medical procedures, when the agenda usage, which is a enduring security methodology planned through the who a critical decrease trendy the examination of ssi rate flanked by the two time frames was proven (Yii and Ng, 2012).

The measure of patients continued in the post-mediation period in this investigation was higher, essentially because of the expansion in tasteful plastic medical procedure performed at the establishment, which was a vital definition to streamline the careful focus, and could be a restricting variable.

Another impediment is the review study plan. Critical decrease in disease rates can be affected by heterogeneity in the gatherings assessed, and by segment attributes and seriousness of the patients, which were not surveyed.

\section{CONCLUSION}

There was a strong connection between applying careful security agenda and result of medical procedure.

\section{REFERENCES}

1. Balsells E, Shi T, Leese C, Lyell I, Burrows J, Wiuff $C$ and Nair H. (2019): Global burden of Clostridium difficile infections: a systematic review and meta-analysis. Journal of Global Health, 9(1): 16-21.

2. Boaz M, Bermant A, Ezri T, Lakstein D, Berlovitz Y and Laniado I. (2014): Effect of Surgical Safety checklist implementation on the occurrence of postoperative complications in orthopedic patients. Isr Med Assoc J., 16(1):20-5.

3. Carvalho, A., Chu, J., Meinguet, C., Kiss, R., Vandenbussche, G., Masereel, B., ... and Mathieu, V. (2017): A harmine-derived betacarboline displays anti-cancer effects in vitro by targeting protein synthesis. European Journal of Pharmacology, 805, 25-35.

4. De Jager E, McKenna C, Bartlett L, Gunnarsson $R$ and Ho YH. (2016): Postoperative adverse events inconsistently improved by the World Health Organization surgical safety checklist: a systematic literature review of 25 studies. World Journal of Surgery, 40(8): 1842-1858.

5. De Vries EN, Prins HA, Crolla RMPH, den Outer AJ and Dijkgraaf MG. (2010): Effect of a comprehensive surgical safety system on patient outcomes. New England Journal of Medicine, 363(20): 1928-1937.

6. El-Sherbiny NA, Ibrahim EH and AbdelWahed WY. (2020): Assessment of patient safety culture among paramedical personnel at general and district hospitals, Fayoum Governorate, Egypt. Journal of the Egyptian Public Health Association, 95(1): 4-9.

7. Lingard L, Regehr G, Orser B, Reznick R, Baker GR, Doran D and Whyte S. (2010): Evaluation of a preoperative checklist and team briefing among surgeons, nurses, and 
anesthesiologists to reduce failures in communication. Archives of Surgery, 143(1): 12-17.

8. Malizos KN and Kirketerp-Møller $\mathrm{K}$. (2016): Incidence and socioeconomic impact of bone and joint infections (BJIs): The European perspective. In Periprosthetic Joint Infections. Pbl. Springer, Cham, Pp. 3-18.

9. Mazzocco K, Petitti DB, Fong KT, Bonacum D, Brookey $J$ and Thomas EJ. (2011): Surgical team behaviors and patient outcomes. The American Journal of Surgery, 197(5): 678-685.

10. Nyarugwe SP, Linnemann A, Hofstede GJ, Fogliano $V$ and Luning P. A. (2016): Determinants for conducting food safety culture research. Trends in Food Science and Technology, 56: 77-87.

11. Platt R, Zaleznik DF, Hopkins CC, Dellinger EP, Karchmer AW, Bryan CS and Tosteson TD. (2010): Perioperative antibiotic prophylaxis for herniorrhaphy and breast surgery. New England Journal of Medicine, 322(3): 153-160.

12. Prates CG, Stadñik CMB, Bagatini A, Caregnato RCA and de Moura GMSS. (2018): Comparison of surgical infection rates after implementation of a safety checklist. Acta Paulista de Enfermagem, 31(2): 116-122.

13. Russ SJ, Sevdalis N, Moorthy K, Mayer EK, Rout S, Caris J and Darzi A. (2015): A qualitative evaluation of the barriers and facilitators toward implementation of the WHO surgical safety checklist across hospitals in England: lessons from the "Surgical Checklist Implementation Project". Annals of Surgery, 261(1): 81-91.

14. Safety WHOP and Organization WH. (2009): WHO guidelines for safe surgery: 2009: safe surgery saves lives (Issue WHO/IER/PSP/2008.08-1E): World Health Organization.

15. Shiralkar, U. (2017): Surgeon, Heal Thyself: Optimising Surgical Performance by Managing Stress. CRC Press.

16. Singh SS, Mehra N and Hopkins L. (2018): No. 286-surgical safety checklist in obstetrics and gynecology. Journal of Obstetrics and Gynecology Canada, 40(3): 237-242.

17. Siu J, Maran $\mathbf{N}$ and Paterson-Brown S. (2016): Observation of behavioural markers of non-technical skills in the operating room and their relationship to intra-operative incidents. The Surgeon, 14(3): 119-128.

18. Urbach DR, Govindarajan A, Saskin R, Wilton AS, and Baxter NN. (2014): Introduction of surgical safety checklists in Ontario, Canada. N Engl J Med, 370: 10291038.

19. Yii MK and Ng KJ. (2012): Risk-adjusted surgical audit with the POSSUM scoring system in a developing country. British Journal of Surgery, 89(1): 110-113. 


\section{السلامة الجراحية و الآثار السلبية في غرف العمليات}

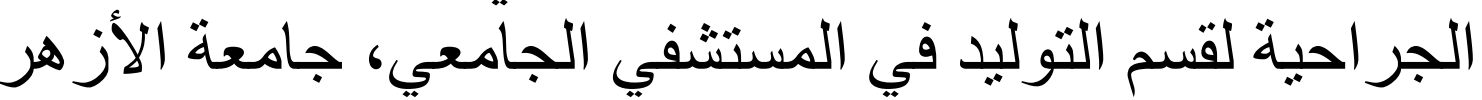

أحمد عبد الغفور البسيوني أبوزيد، إسماعيل طلعت الجارحي، عادل علي البغدادي

قسم التوليد و أمراض النساء، كلية الطب، جامعة الأزهر

E-mail: $\underline{\text { dr_ahmed_basiony@hotmail.com }}$

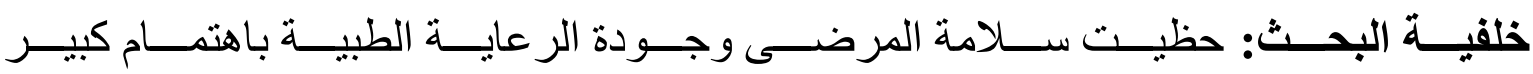

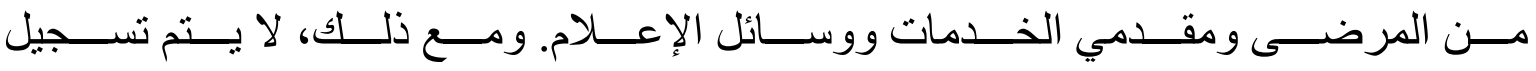

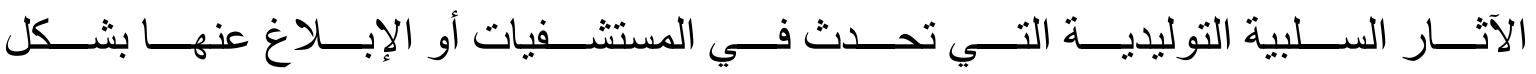

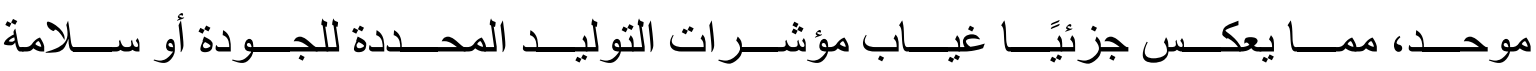

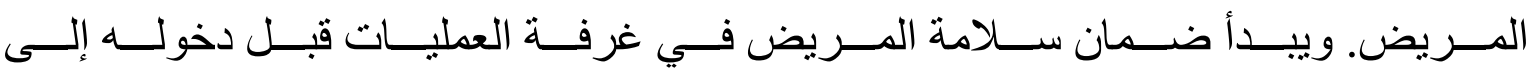

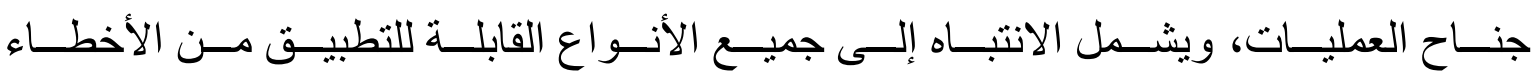
الطبية التي يمكن الوقاية منها.

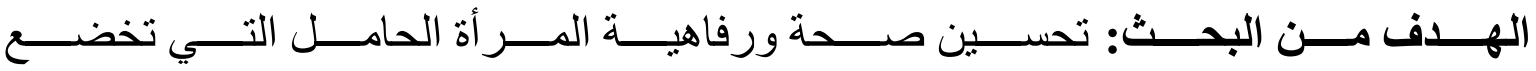
لجر احة التوليد في مستشفى الأزهر الجامعي. لوني.

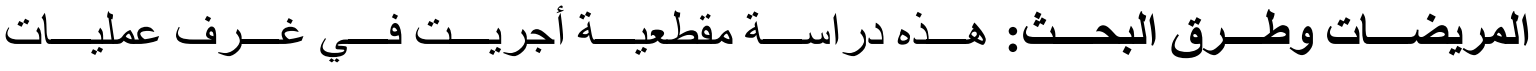

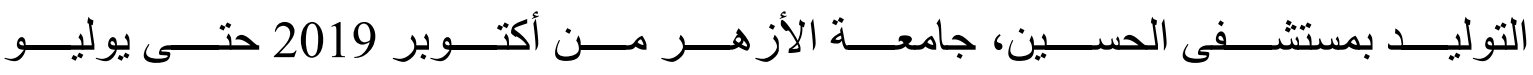

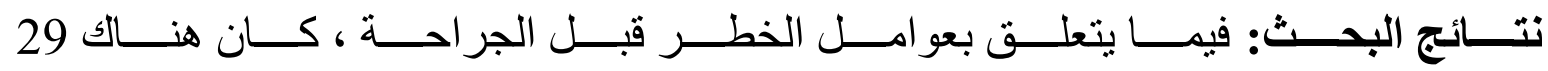

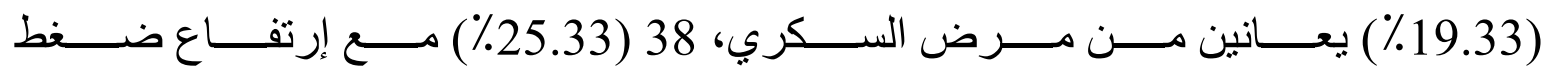

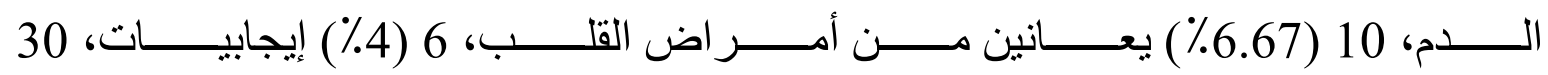

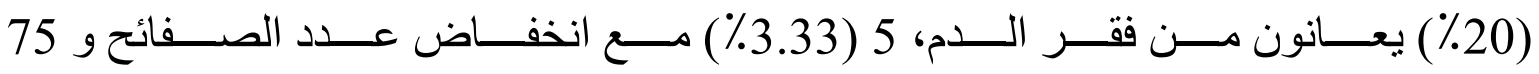

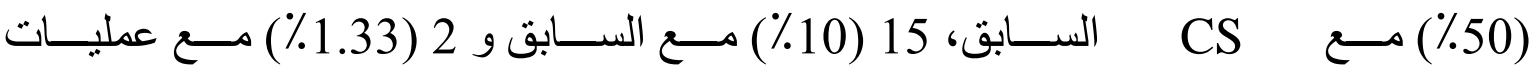

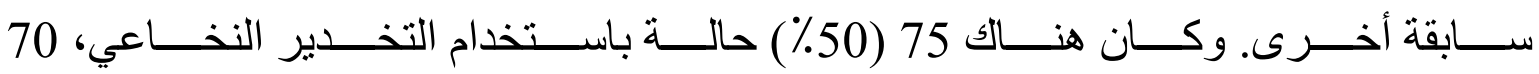

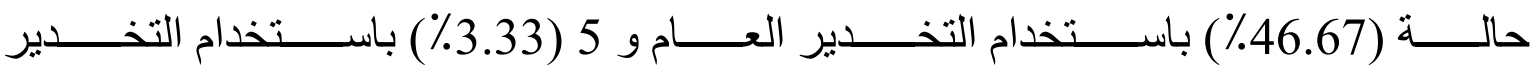


العام.وقــد خضـــع أكبـر نســبة مــن المريضــات لعمليــات تـم فيهـــا اســتيفاء بنــود قائمسـة

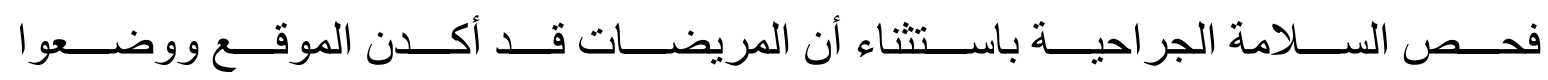

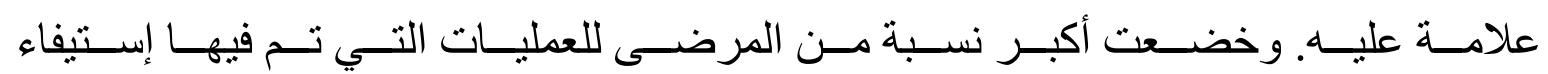

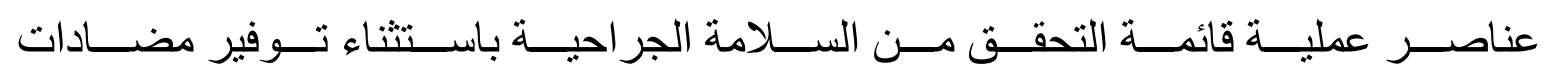
حيوية وقائية ونأكيد شفوي لهوية المريض وموقع الجراحة. الاستنتاج: هنالك علاقة قوية بين تطبيق أجندة أمنية دقيقة.

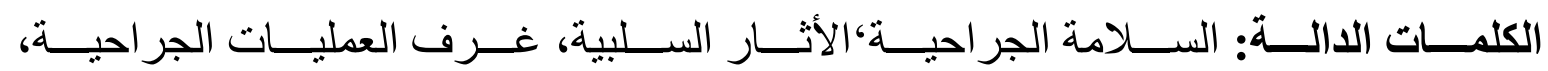
قسم التوليد. 